\title{
Epilepsy in the cancer patient
}

Odysseas Kargiotis $^{1,2}$; Sofia Markoula ${ }^{3}$; Athanasios P. Kyritsis ${ }^{1,3}$

${ }^{1}$ Neurosurgical Research Institute, University of Ioannina, Ioannina, Greece

${ }^{2}$ Department of Neurology, University Hospital of Patras Medical School, Patra,

Greece

${ }^{3}$ Department of Neurology, University Hospital of Ioannina Medical School, Ioannina,

Greece

Correspondence to:Odysseas Kargiotis, M.D.,

Dept. of Neurology,

University of Patras School of Medicine,

University Campus

Patras 26504, Greece

Phone: +30 2610999572

Fax: +30 2610993949

Email:kargiody@mycosmos.gr 


\begin{abstract}
Purpose: Epileptic seizures in patients with malignancies usually occur as a consequence of brain metastases from systemic cancer or the presence of a primary brain tumor. Other less frequent causes include metabolic disorders such as electrolyte abnormalities, hypoglycemia, hypoxia and liver failure, paraneoplastic encephalitis, leptomeningeal carcinomatosis, side effects of certain chemotherapeutic agents, central nervous system infections and pre-existing epilepsy.

Methods: We reviewed all published literature in the English language regarding use of antiepileptic drugs in patients with cancer.

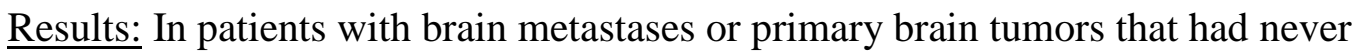
experienced seizures, prophylactic anticonvulsant treatment is justified only for a period up to six months postoperatively after surgical excision of a cerebral tumor, since approximately half of the patients will never develop seizures and the anti-epileptic drugs may cause toxicity and interactions with antineoplastic therapies. For brief prophylaxis, newer antiepileptic drugs such as levetiracetam and oxcarbazepine are superior to older agents like phenytoin. In patients with a malignancy and seizures, certain antiepileptic drugs that express tumor inhibitory properties should be used such as valproic acid and levetiracetam, followed by oxcarbazepine and topiramate that exhibit good tolerance, efficient seizure control and absence of significant interactions with the chemotherapy.

Conclusions: Future clinical trials in patients with cancer and epilepsy should focus on combinations of chemotherapeutic interventions with antiepileptic drugs that demonstrate antineoplastic activities.
\end{abstract}

Keywords: cancer; antiepileptics, chemotherapy; valproic acid; levetiracetam 


\section{Introduction}

Epileptic seizures may occur in patients with systemic cancer for a variety of reasons [1]. Primary and metastatic brain tumors are frequently complicated by symptomatic epilepsy, defined as recurrent unprovoked seizures or single isolated seizure episode, both associated to the brain lesion. Brain tumor patients with seizures account for the $4 \%$ of epilepsy patients [2]. In some cases, seizures might be the presenting symptom that will lead to the detection of the tumor, whereas alternatively seizures may represent a later manifestation following initial diagnosis or tumor recurrence. Epilepsy accompanies primary intracranial neoplasms in more than $30 \%$ of the cases; however a great variety in frequency exists among different tumor types. Similar incidence rates are reported for brain metastases, ranging from 25 to $40 \%$ [3].

In this review we discuss the various causes of seizures in cancer patients and we briefly discuss the possible epileptogenic mechanisms. Moreover, we analyze the efficacy of the available antiepileptic pharmaceutical agents and the possible interactions with chemotherapeutic drugs. Finally, we focus on another aspect of antiepileptic treatment, which involves the potential antitumoral effects of certain agents and their potency to enhance current or future cytotoxic therapies.

\section{Incidence and causes of seizures in cancer patients}

In patients with cancer, epileptic seizures are mainly triggered by brain metastases or other focal cerebral abnormality and rarely by metabolic disorders such as electrolyte abnormalities, hypoglycemia, hypoxia and liver failure [4]. Other conditions predisposing to epilepsy include paraneoplastic encephalitis [5] and leptomeningeal carcinomatosis [6]. Chemotherapeutic agents, such as methotrexare, vincristine, ifosfamide, cyclosporine, fludarabine, cytarabine and cisplatin may also induce an 
encephalopathy with seizures [7]. Radionecrosis in brain areas and opportunistic central nervous system (CNS) infections are other causes of seizures [3].

Regarding primary brain tumors, epileptic seizures will lead to the initial detection of the intracranial lesion in 30 to $50 \%$ of the patients [8]. In primary brain tumors, epileptogenesis is dependent upon histological type, location, grade, as well as upon the individual's genetic susceptibility. Less aggressive tumor types are proven to be more epileptogenic. It has been suggested that slow growth rates allow for the tumor to gradually infiltrate adjacent areas and induce an epileptic foci by creating abnormal circuits and by preventing normal brain tissue's self-regulation and inhibition locally [9]. In addition, survival rates are higher, resulting in more patients developing seizures at some point of the disease progression, since they are exposed for a longer period to the irritating effects of the lesion. This is particularly evident in gliomas, where 60 to $85 \%$ of the patients with low grade astrocytomas and oligodendrogliomas suffer from epilepsy, whereas in glioblastoma multiforme the percentage is significantly lower, ranging from 30 to $50 \%$ [10]. In a previous study of 119 patients with supratentorial gliomas, half of them presented with seizures, whereas preoperative incidence of epilepsy was $83 \%$ in patients with low-grade astrocytoma, $46 \%$ in anaplastic astrocytoma and $36 \%$ in glioblastoma [11]. In addition, dysembryoblastic neuroepithelial tumors and gangliogliomas represent the most epileptogenic brain tumors with a seizure incidence of $100 \%$ and $80-90 \%$ respectively [12]. Epilepsy is less frequent in meningiomas, ranging from 22 to $60 \%$, although surgical resection may provoke post-treatment seizures in $20 \%$ of the patients without such manifestations before surgical intervention [13].

Irrespective of the tumor type and despite the antiepileptic treatment, when seizures are the presenting symptom of a tumor the patient is at increased risk of 
developing recurrent seizures [14]. Regarding location, tumors developing within the brain cortex are typically more epileptogenic, especially those detected at the frontal, temporal and parietal lobes. On the other hand, sellar neoplasms and those located in the posterior fossa do not usually cause seizures [15].

\section{Provoking mechanisms}

Several pathophysiological mechanisms are proposed as capable of triggering epileptic seizures in patients with brain tumors. These include the disruption of neuronal connections and inhibition of local network regulation, the impaired glial cell activity, the increased vascular permeability and the abnormal function of the blood brain barrier. In addition, rapidly growing tumors deregulate adjacent areas and result in peritumoral edema and inflammation, necrosis and hemosiderin deposition. These events might initialize abnormal circuits leading to seizure activity in the brain $[16,17]$.

In low grade gliomas, partial deafferentiation of adjacent cortical areas is believed to provoke seizures [18]. Malignant brain tumors demonstrate increased metabolic rates and rapid cell growth leading to hypoxia and acidosis within and around the tumor mass as well as central necrosis, factors that contribute to neuronal excitability [19].

Moreover, adjacent brain cortex tissue is exposed to higher levels of several enzymes, such as lactate, enolase and adenosine 3',5'-cyclic monophosphate (cAMP) phosphodiesterase, creating a metabolic imbalance and predisposing to generation of abnormal electrical events [20]. The enhancement of intercellular signaling exchange between neurons is believed to occur as a consequence of the increased expression of the transmembrane gap junction molecules connexins that is frequently observed in epileptogenic brain tumors [21]. 
Perhaps the most extensively studied mechanism involves the role of the altered neurotransmitter receptor expression in brain tumors. Gliomas display increased expression of glutamate receptors, enhanced glutamate activity and decreased expression of GABA receptors in the adjacent brain tissue [22]. The up-regulation of molecules such as the kainite and the N-methyl-D-aspartic acid (NMDA) receptors suppresses inhibitory signals and allows for the generation of potent epileptogenic foci $[23,24]$.

\section{Indications of antiepileptic drug treatment}

Therapeutic strategies in patients with cancer and epilepsy must integrate an optimal antiepileptic medication. However, many physicians tend to prescribe antiepileptic agents in newly-diagnosed patients with primary or metastatic brain tumors, even in the absence of seizures, based on the fact that epilepsy may occur later during the course of the disease [25]. Two recent meta-analyses failed to provide with sufficient evidence favoring prophylactic anticonvulsant medication in brain tumors. The first by Glantz et al (2000), analyzed 12 studies with 4 of them providing with level I evidence [14]. The study by Sirven et al (2004) examined five clinical trials that included patients with primary glial tumors, cerebral metastases or meningiomas and no history of seizures. The antiepileptics used were phenobarbital, phenytoin and valproic acid and patient evaluation lasted up to six months. Lack of antiepileptic prophylactic effect was documented, irrespective of tumor type or pathology [26].

In the study by Rosati et al (2009) patients with brain tumors were considered epileptics and subsequently anticonvulsant treatment was administered if they have had a single convulsive seizure attack with evidence of interictal epileptiform abnormalities in the EEG; had stereotypic symptoms suggestive of focal seizures with or without 
interictal epileptiform abnormalities; or had experienced a single epileptic seizure episode associated with stereotypic symptoms suggestive of focal seizure with or without interictal epileptiform abnormalities. The authors introduced the term of remote symptomatic seizure in cases of a single seizure and no interictal epileptiform abnormalities or stereotypic symptoms suggestive of focal seizure and distinguished it from symptomatic epilepsy that requires treatment. Among the 35 patients who did not fulfill the criteria to receive antiepileptic treatment none developed seizures during the follow-up period or until death [27].

A more recent meta-analysis that included all articles from 1966 to 2007 referring to prophylactic treatment with phenytoin, phenobarbital, and valproic sodium, found no difference between treated and control groups in terms of the prevention of the first seizure episode in patients with brain tumors. Additionally, the risk of an adverse event was higher for patients on antiepileptic drugs than for controls [28]. Regarding brain metastases, a study by Forsyth et al (2003) including 60 patients found no significant prophylactic benefit from antiepileptic drugs [29]. Similarly, a recent meta-analysis did not support routine prophylactic anticonvulsant treatment in patients without seizures [30].

Questionable remains the efficacy of postoperative administration of antiepileptics after brain tumor resection in patients without epileptic manifestations prior to surgery [31]. However, Franceschetti et al (1990) studied 128 patients with surgically treated brain tumors and reported a significant benefit from short-term antiepileptic drug prophylaxis in patients without preoperative seizures, but again did not observe longterm prophylactic effectiveness [32]. Similarly, Pace et al (1998), by investigating 119 glioma patients that received prophylactic treatment with phenobarbital, carbamazepine or vigabatrin postoperatively found a high incidence of adverse reactions, 33.8, 14.3 and 
$12 \%$ respectively, and concluded that long-term prophylactic anticonvulsants are not indicated [11]. On the other hand, a study that evaluated the early postoperative prophylaxis with oxcarbazepine in 150 glioma patients, showed significant benefit, since seizure incidence was reduced to $2.7 \%$ within the first week [33]. Furthermore, a very recent study reported significant pre and postoperative prophylaxis, along with minimal toxicity with levetiracetam in patients with primary or metastatic brain tumors. Since $38 \%$ had experienced preoperative seizures and $97.5 \%$ of all patients remained seizure-free at the end of observation, this study clearly favors levetiracetam's use as a prophylactic antiepileptic in surgically treated brain tumors [34].

Thus, antiepileptic drug prophylaxis is not indicated in patients with primary or metastatic brain tumors and without a definite history of seizures. However, short term anticonvulsant prophylaxis after surgical excision of the tumor mass could represent an acceptable clinical practice, since up to $13 \%$ of the patients may experience seizures within the first postoperative week, irrespective of the presence of preoperative seizure history or not [35].

\section{Efficacy of antiepileptic medications}

The management of symptomatic epilepsy in patients with cancer consists mainly of the selection of the appropriate antiepileptic drug. Several older agents, such as carbamazepine, phenytoin, phenobarbital, valproic acid and newer ones, like levetiracetam, lamotrigine, gabapentin and topiramate are included within a list of drugs indicated for epilepsy. Currently, there are no guidelines how to treat patients with secondary, brain tumor-induced epilepsy. Thus, the clinician is expected to select the most appropriate medication, sometimes for each patient individually, by taking into consideration efficacy, tolerability, adverse effects, interactions with co-administrated 
pharmaceutical agents and perhaps the possible influence on tumor growth and progression.

An important aspect of an optimal antiepileptic drug therapy is its efficacy to control seizures in conjunction with limited adverse effects. Several clinical studies have documented superior effectiveness and /or tolerability of levetiracetam that exerts its effects through binding to synaptic vesicle protein SV2A [36]. A study of levetiracetam in 18 patients with primary brain tumors and refractory epilepsy showed significant response in all patients, $89 \%$ of which remained seizure-free with minimal adverse reactions [37]. Similarly, superior results were obtained from the use of levetiracetam compared to phenytoin in a cohort of post craniotomy glioma patients [38, 39]. Regarding metastatic tumors, levetiracetam reduced seizure frequency to more than $50 \%$ in all 13 patients followed, leaving the majority of them seizure free $(77 \%)$, while the most common complaints included headaches and somnolence [40]. The same authors studied a mixed patient population with primary and metastatic brain tumors treated with levetiracetam -primarily as monotherapy- and observed significant antiepileptic efficacy in $90 \%$ of the patients [41]. As add on therapy, levetiracetam was evaluated in 19 glioma patients suffering from refractory epilepsy. The authors reported a significant response in 14 patients with no remarkable adverse reactions [42]. The most frequent side effects of levetiracetam include psychomotor disturbances, insomnia and somnolence. On the other hand, the drug exerts antiemetic properties of unknown mechanism, which may prove useful in patients receiving chemotherapy [43].

Satisfactory seizure control in brain tumor patients may also be achieved by valproic acid. Van Breemen et al (2009) investigated 99 glioma patients with secondary epilepsy and reported response rates of $79.3 \%$ with valproic acid as monotherapy and $81.5 \%$ with the combination of valproic acid and levetiracetam, while 52\% and 59\% 
remained entirely seizure free [44]. The administration of topiramate was also associated with efficient seizure control in patients with secondary epilepsy due to brain tumors. The response rate was $75.6 \%$ and along with the mild side effects offered an adequate antiepileptic intervention [45]. Similar results were obtained from the use of oxcarbazepine, reporting fewer adverse reactions and at least equal with the older medications antiepileptic effect [46].

Based on clinical studies and pharmacological profiles, Vecht and Wilms (2010) suggested initializing the anticonvulsant treatment with levetiracetam and in case of inadequate response, the co-administration of valproic acid due to the possible synergistic effects. Topiramate and lamotrigine could be used instead of valproic acid to assist levetiracetam's activity [47]. Another anticonvulsant as add on medication could be gabapentin, reported to decrease seizure frequency to $50 \%$ in a small group of brain tumor patients, leaving half of them seizure free [48]. Van Breemen et al (2007) considered as first-line agents lamotrigine, valproic acid and topiramate, whereas levetiracetam or gabapentin could be used as add on agents in refractory cases [3].

In 12 patients with refractory brain tumor epilepsy, tiagabine as add on therapy was well tolerated and augmented seizure control in 7 of them [49]. Pregabalin, either as monotherapy or in conjunction with other antiepileptics, produced an excellent response in all nine patients applied, but was accompanied by an increased rate of adverse affects [50]. Villanueva et al (2008) argued that hepatic enzyme inducing antiepileptics and valproic acid should be avoided since these drugs either reduce activity or enhance toxicity of chemotherapy. They recommend the newer antiepileptics like vigabatrin, levetiracetam, gabapentin and pregabalin followed by lamotrigine, oxacarbazepine, topiramate and zonisamide which do not influence the pharmacologic profile of chemotherapeutics [6]. Maschio et al (2010) followed 30 patients with secondary 
epilepsy due to brain metastatic disease and concluded that levetiracetam, oxcarbazepine and topiramate may be preferable for this group of patients, since they are well-tolerated, have minimal interactions with other drugs and reduce significantly the seizure frequency [51].

\section{Limitations and complications of antiepileptic medications}

Serious side effects of anticonvulsant medications, such as skin reactions, hematological complications and cognitive impairment seem to occur more frequently in cancer patients $[46,52,53]$. Concomitant therapeutic interventions could result in increased toxicity by the antiepileptic drugs. Thus, phenytoin may cause erythema multiforme and Steven-Johnson's syndrome when simultaneously administrated with cranial irradiation, a complication reported also by the use of carbamazepine $[54,55,56,57]$.

Antiepileptics in conjunction with radiotherapy for low-grade gliomas have been associated with poor performance in various cognitive domains, such as attention and executive function [58]. In addition, valproic acid, as well as carbamazepine, phenobarbital and phenytoin may cause severe hematologic complications, such as platelet and neutrophil depletion and are also associated with a common incidence of encephalopathy $[10,26]$.

Furthermore, some antiepileptic agents interfere with the activity of enzymes crucial for metabolizing common chemotherapeutic agents resulting in either reduction of chemotherapeutic drug clearance and subsequent increased toxicity or in accelerated clearance and reduced chemotherapeutic efficacy (Table 1). On the other hand, the metabolism of the antiepileptic drug itself is related to the co-administrated chemotherapy and it could be either enhanced or suppressed. Since antiepileptic drugs 
exert narrow therapeutic index, their pharmacokinetic profile may be easily altered [59]. Cytochrome P450 (CYP) is a family of enzymes implicated in the metabolism of various endogenous and exogenous molecules. Carbamazepine, phenytoin, phenobarbital, primidone and to a much lesser extend oxcarbazepine and topiramate are potent inducers of CYP and possibly of glucuronyl transferases and epoxide hydrolase, whereas valproic acid exerts inhibitory effects upon CYP isoenzymes. Levetiracetam, gabapentin, lamotrigine and vigabatrin do not significantly influence CYP activity. The three isoenzymes CYP3A4, CYP2C9 and CYP2C19 have the greatest affinity for both antiepileptic and anticancer drugs [60, 61]. Examples of antineoplastic drugs that are eliminated rapidly from circulation due to the induction of hepatic enzymes include busulfan, methotrexate, irinotecan, tamoxifen, etoposide, paclitaxel, vincristine, procarbazine, cisplatin and topotecan [62]. Valproic acid though, by exerting inhibitory enzyme activity, may increase concentrations of nitrosureas, cisplatin and etoposide leading to subsequent toxicity and imposing the reduction of the antineoplastic agent's dose [61].

Since anticonvulsant medications are frequently introduced in patients with cancer, clinical trials testing novel therapeutic strategies might benefit from taking into account the possible drug interactions. Imatinib mesylate, an agent used to treat certain types of cancer, is primarily metabolized by the CYP3A4 isoenzyme and anticonvulsants up-regulating CYP3A4 result in a 2.9 fold reduction of imatinib's levels [63]. The maximal tolerated dose of erlotinib in patients with recurrent glioblastoma or meningioma is significantly higher when co-administrated with enzyme inducing antiepileptics [64]. Such interactions are crucial in determining the dosage of anticancer drugs in different groups of patients. 
On the other hand, chemotherapeutic agents, such as methotrexate, doxorubicin and cisplatin, through an enzyme induction mechanism, can decrease efficacy of valproic acid, carbamazepine and phenytoin [65]. Doxifluridine, fluorouracil and tamoxifen may reduce the metabolism rate of antiepileptic drugs (phenytoin) and increase susceptibility to toxicity [59]. Moreover, the interactions between anticancer and antiepileptic agents are also determined by their protein bounding capacity. In this way, phenytoin, phenobarbital and valproic acid compete with cisplatin, etoposide and teniposide for plasma protein bounding resulting in alterations of the unbound and active proportion of each drug. Furthermore, phenytoin, carbamazepine and phenobarbital minimize the activity of corticosteroids which are irreplaceable agents in most patients with brain tumors [65].

Overexpression of molecules located on brain endothelial cells that function as modulators of drug transport through the blood brain barrier increase further resistance to antiepileptics. Expression of P-glycoprotein and multidrug resistance proteins 3 and 5 has been found up-regulated in glioma specimens and since these factors decrease the intracerebral access of antiepileptics such as carbamazepine, phenytoin, phenobarbital, lamotrigine and felbamate, it is argued that resistance to antiepileptic drug therapy in brain tumors is associated with altered transportation properties through the blood brain barrier $[66,67]$. To overcome this limitation, the use of drugs not susceptible to Pglycoptrotein dependence, such as levetiraceram, might prove beneficial to control seizures [62].

\section{Antitumoral effects of antiepileptic drugs}

An ideal therapeutic approach against seizures in patients with cancer would include the administration of antiepileptic agents that have antitumor activity. However, among the 
wide range of anticonvulsants, only valproic acid has been associated with anticancer properties and representative studies are presented in table 2. Although in clinical use for decades, it was not until recently that valproic acid was recognized as a histone deacetylase inhibitor (HDACi), capable of inhibiting both class I and II histone deacetylases, resulting in hyperacetylation of histones $\mathrm{H} 3$ and $\mathrm{H} 4[68,69]$. Alterations in the acetylation status of chromatin influence its structure, in a way that it is maintained in a more open conformation, allowing to previously silenced genes to be activated and to previously overexpressed genes to be inhibited. Several molecular pathways have been shown to be affected by valproic acid via gene expression regulation, such as those incorporating ribosomal proteins, oxidative phosphorylation pathways, mitogen activated protein kinase (MAPK) signaling, focal adhesion pathways, cell cycle regulation, antigen processing and presentation processes, proteasome and apoptosis pathways, phosphoinositide 3-kinase (PI3K) and Wnt signaling, calcium and transforming growth factor-beta (TGF-beta) signaling and ubiquitin-mediated proteolysis. For this reason, valproic acid could interfere with crucial cellular processes of carcinogenesis like cell differentiation, proliferation, apoptosis and migration [70].

Tested in C6 glioma cells, valproic acid induces neuronal differentiation, along with growth arrest and suppression of cell migration [71]. Similar effects were observed in malignant neuroblastoma cells, where morphological changes compatible with neuronal differentiation were accompanied by down-regulation of $\mathrm{N}$-myc, induction of bcl-2 and neural cell adhesion molecule and up-regulation of the excreted antiangiogenic factors thrombospondin-1 and activin A. Moreover, valproic acid was shown to act in a synergistic manner towards these antitumoral effects with interferonalpha [72]. In combination with interferon-gamma, valproic acid increased caspase- 8 
promoter activity in medulloblastoma cells, rendering them vulnerable to tumor necrosis factor-related apoptosis-inducing ligand (TRAIL) mediated apoptosis and suppressed tumor growth in vivo [73]. Regarding cell growth, most studies with valproic acid report reduced proliferation rates and/or apoptosis in different malignant cell types [74]. Valproic acid treatment resulted in up-regulation of p21/WAF1, suppression of CDK4 and cell cycle arrest $[75,76,77]$.

Besides causing growth arrest and apoptosis, valproic acid may also interfere with other fundamental processes of carcinogenesis. For instance, valproic acid decreased the invasive capacity of neural crest-derived human tumor cell lines via inhibition of matrix metalloproteinases-2 and -9 (MMPs) and induction of tissue inhibitor of metalloproteinases-1 [78]. In addition, in vivo medulloblastoma models treated with valproic acid display decreased growth rates and angiogenesis [79].

Several studies aimed to introduce simultaneous anticancer and antiepileptic therapeutic interventions by taking advantage of valproic acid's gene modulating properties. In this way, valproic acid enhanced the cytotoxicity of nitrosoureas and etoposide in glioma cells and synergized with interferon alpha and gamma to suppress neuroblastoma and medulloblastoma growth respectively $[72,73,75,80]$. Valproic acid up-regulated melatonin MT1 receptor expression in C6 glioma and breast cancer cells and in combination with melatonin inhibited cell proliferation [81]. In association with rapamycin, LY294002 and temozolomide, valproic acid triggered autophagic death in glioma cells [82]. Since valproic acid's anticancer activity has been documented in a number of solid tumors, including some that frequently invade the brain, its potent antitumoral effect against brain metastases remains to be clarified [70].

Interestingly, the valproic acid-induced hyperacetylation of histones may contribute to the enhancement of radiotoxicity in tumor cells. Thus, the growth of brain 
tumor xenografts in mice was further inhibited when irradiation was combined with valproic acid administration [83]. Similarly, Chinnaiyan et al (2008) reported that radiosensitization of glioma cells by valproic acid was sustained up to 24 hours and involved the modulation of DNA repair processes associated with the histone gammaH2AX [84].

Recently, Bobustuc et al (2010) evaluated the effect of antiepileptics on O(6)methylguanine-DNA methyltransferase (MGMT) expression in gliomas [85]. MGMT is a DNA repair enzyme that has been recognized to play a pivotal role in enhancing resistance to alkylating drugs, such as temozolomide. MGMT is frequently up-regulated in gliomas, rendering alkylating treatment insufficient [86]. In a clinical study, endogenous methylation and subsequent silencing of MGMT promoter proved to be an independent favorable prognostic factor in patients with glioblastoma. Moreover, only patients with tumors harboring a methylated MGMT promoter benefited from temozolomide treatment [87]. In the study by Bobustuc et al (2010), it was shown that levetiracetam is a potent inhibitor of MGMT that augments p53 binding on the MGMT promoter by recruiting the $\mathrm{mSin} 3 \mathrm{~A} /$ histone deacetylase 1 (HDAC1) co-repressor complex. Subsequently, levetiracetam sensitized glioma cells to temozolomide. Thus, it was suggested that in glioblastoma cases with MGMT over-expression, levetiracetam may enhance the cytotoxic effect of chemotherapy [85].

Limited data in the literature is available regarding the influence of antiepileptic drugs on survival of patients with brain tumors. Non-enzyme inducers and particularly valproic acid which exerts tumor inhibitory effects, is shown to prolong survival of glioblastoma patients receiving CCNU chemotherapy compared to enzyme inducers (carbamazepine) [88]. On the contrary, a more recent study reported enhanced overall survival of glioblastoma patients receiving enzyme-inducing anticonvulsants, without 
proposing an explanation for the mechanism other than the possible increased toxicity by non-enzyme inducers [89]. The application of enzyme inducing antiepileptics in pediatric patients with acute lymphoblastic leukemia, receiving concomitant chemotherapy, was associated with increased hematological toxicity and CNS relapse as well as worse event-free survival. The authors documented accelerated clearance of teniposide and methotrexate but not of cytarabine and linked the unfavorable outcome to the lower efficacy of chemotherapy due to the up-regulation of catabolic enzymes (90).

Table 3 summarizes the results from some important clinical studies analyzed in this review. Large scale clinical studies are needed to investigate the possible antitumoral contribution of certain antiepileptics in humans with primary or metastatic brain tumors. There is preclinical evidence that molecular targeted combination of these agents with the available therapeutic interventions might offer survival benefit in patients with cancer. Although recent clinical studies evaluating seizure control reported conflicting results regarding overall survival by the use of valproic acid in patients receiving anticancer treatment, these studies were not designed to take advantage of the possible antitumoral and synergistic mechanisms of action of valproic acid according to preclinical data $[44,88,89]$.

\section{Conclusion}

The management of cancer-related epilepsy is often challenging but also very substantial for the patients, the majority of which are associated with an unfavorable survival outcome. An algorithm for the proper selection of an antiepileptic drug in patients with cancer and epilepsy is depicted in figure 1. Although patients with primary or metastatic brain tumors are susceptible to epileptic seizures, prophylactic 
anticonvulsant treatment is not indicated, since many patients may never develop seizures and in addition it can increase unnecessary toxicity. However, the prophylactic use of anticonvulsants could be an acceptable decision postoperatively, after surgical excision of the tumor mass and for a limited time period, less than 6 months, provided that the patient has remained seizure free after surgery. For such antiepileptic prophylaxis newer agents, such as levetiracetam and oxcarbazepine are superior to older ones like phenytoin. In patients with brain tumor induced epilepsy, certain antiepileptics, such as levetiracetam and valproic acid, are beneficial. Alternative antiepileptic drugs include oxcarbazepine and topiramate because of their tolerance, efficient seizure control and absence of significant interactions with anticancer drugs. Controlling the epileptic seizures and contributing to tumor suppression simultaneously would represent an attractive therapeutic approach against primary or metastatic brain tumors. 


\section{References}

1. Grewal J, Grewal HK, Forman AD (2008) Seizures and epilepsy in cancer: etiologies, evaluation, and management. Curr Oncol Rep 10:63-71.

2. Herman ST. Epilepsy after brain insult: targeting epileptogenesis (2002) Neurology 59(Suppl):S21-S26.

3. van Breemen MS, Wilms EB, Vecht CJ (2007) Epilepsy in patients with brain tumours: epidemiology, mechanisms, and management. Lancet Neurol. 6:421430.

4. Bromfi eld EB (2004) Epilepsy in patients with brain tumors and other cancers. Rev Neurol Dis 1 (suppl 1): S27-33.

5. Sioka C, Fotopoulos A, Kyritsis AP(2010) Paraneoplastic neurological syndromes and the role of PET imaging. Oncology.78:150-156.

6. Villanueva V, Codina M, Elices E (2008) Management of epilepsy in oncological patients. Neurologist 14(6 Suppl 1):S44-54

7. Sioka C, Kyritsis AP (2009) Central and peripheral nervous system toxicity of common chemotherapeutic agents. Cancer Chemother Pharmacol. 63:761-767.

8. Wen PY, Marks PW (2002) Medical management of patients with brain tumors. Curr Opin Oncol 14:299-307.

9. Samji MF, Fric-Shamji EC, Benoit BG (2009) Brain tumors and epilepsy: pathophysiology of peritumoral changes. Neurosurg Rev 32:275-285.

10. Moots PL, Maciunas RJ, Eisert DR, Parker RA, Laporte K, Abou-Khalil B (1995) The course of seizure disorders in patients with malignant gliomas. Arch Neurol 52:717-724. 
11. Pace A, Bove L, Innocenti P, Pietrangeli A, Carapella CM, Oppido P, Raus L, Occhipinti E, Jandolo B (1998) Epilepsy and gliomas: incidence and treatment in 119 patients. J Exp Clin Cancer Res. 17:479-482.

12. Villemure JG, de Tribolet N (1996) Epilepsy in patients with central nervous system tumors. Curr Opin Neurol 9:424-428.

13. Lieu AS, Howng SL (2000) Intracranial meningiomas and epilepsy: incidence, prognosis and influencing factors. Epilepsy Res. 38:45-52.

14. Glantz MJ, Cole BF, Forsyth PA, Recht LD, Wen PY, Chamberlain MC, Grossman SA, Cairncross JG (2000) Practice parameter: anticonvulsant prophylaxis in patients with newly diagnosed brain tumours. Reported of the Quality Standard Subcommittee of the American Academy of Neurology. Neurology 54:1886-1893.

15. Liigant A, Haldre S, Oun A, Linnamagi U, Saar A, Asser T, Kaasik AE (2001) Seizure disorders in patients with brain tumors. Eur Neurol 45:46-51.

16. Rajneesh KF, Binder DK (2009) Tumor-associated epilepsy. Neurosurg. Focus 27: E4.

17. Beaumont A, Whittle IR (2000) The pathogenesis of tumour associated epilepsy. Acta Neurochir (Wien) 142:1-15.

18. Kurzwelly D, Herrlinger U, Simon M (2010) Seizures in patients with low-grade gliomas--incidence, pathogenesis, surgical management, and pharmacotherapy. Adv Tech Stand Neurosurg. 35:81-111.

19. Schaller B (2005) Influences of brain tumor-associated pH changes and hypoxia on epileptogenesis. Acta Neurol Scand. 111:75-83.

20. Kim E, Lowenson JD, MacLaren DC, Clarke S, Young SG (1997) Deficiency of a protein-repair enzyme results in the accumulation of altered proteins, 
retardation of growth, and fatal seizures in mice. Proc Natl Acad Sci U S A. 94:6132-6137.

21. Aronica E, Gorter JA, Jansen GH, Leenstra S, Yankaya B, Troost D(2001) Expression of connexin 43 and connexin 32 gapjunction proteins in epilepsyassociated brain tumors and in the perilesional epileptic cortex. Acta Neuropathol 101:449-459.

22. Bateman DE, Hardy JA, McDermott JR, Parker DS, Edwardson JA (1988) Amino acid neurotransmitter levels in gliomas and their relationship to the incidence of epilepsy. Neurol Res 10:112-114.

23. Maas S, Patt S, Schrey M, Rich A(2001) Underediting of glutamate receptor GluR-B mRNA in malignant gliomas. Proc Natl Acad Sci U S A. 98:1468714692.

24. Mody I, Heinemann U(1987) NMDA receptors of dentate gyrus granule cells participate in synaptic transmission following kindling. Nature 326:701-704.

25. Siomin V, Angelov L, Li L, Vogelbaum MA (2005) Results of a survey of neurosurgical practice patterns regarding the prophylactic use of anti-epilepsy drugs in patients with brain tumors. J Neurooncol. 74:211-215.

26. Sirven JI, Wingerchuk DM, Drazkowski JF, Lyons MK, Zimmerman RS (2004) Seizure prophylaxis in patients with brain tumors: a metanalysis. Mayo Clin Proc 79:1489-1494.

27. Rosati A, Tomassini A, Pollo B, Ambrosi C, Schwarz A, Padovani A, Bonetti B (2009) Epilepsy in cerebral glioma: timing of appearance and histological correlations. J Neurooncol. 2009 93:395-400. 
28. Tremont-Lukats IW, Ratilal BO, Armstrong T, Gilbert MR (2008) Antiepileptic drugs for preventing seizures in people with brain tumors. Cochrane Database Syst Rev. 16:CD004424. Review

29. Forsyth PA, Weaver S, Fulton D, Brasher PM, Sutherland G, Stewart D, Hagen NA, Barnes P, Cairncross JG, DeAngelis LM (2003) Prophylactic anticonvulsants in patients with brain tumour. Can J Neurol Sci 30:106-112.

30. Mikkelsen T, Paleologos NA, Robinson PD, Ammirati M, Andrews DW, Asher AL, Burri SH, Cobbs CS, Gaspar LE, Kondziolka D, Linskey ME, Loeffler JS, McDermott M, Mehta MP, Olson JJ, Patchell RA, Ryken TC, Kalkanis SN (2010) The role of prophylactic anticonvulsants in the management of brain metastases: a systematic review and evidence-based clinical practice guideline. $\mathrm{J}$ Neurooncol. 96:97-102.

31. Shaw MD (1990) Post-operative epilepsy and the efficacy of anticonvulsant therapy. Acta Neurochir Suppl (Wien). 50:55-57.

32. Franceschetti S, Binelli S, Casazza M, Lodrini S, Panzica F, Pluchino F, Solero CL, Avanzini G (1990) Influence of surgery and antiepileptic drugs on seizures symptomatic of cerebral tumours. Acta Neurochir (Wien) 103:47-51.

33. Mauro AM, Bomprezzi C, Morresi S, Provinciali L, Formica F, Iacoangeli M, Scerrati M (2007) Prevention of early postoperative seizures in patients with primary brain tumors: preliminary experience with oxcarbazepine. J Neurooncol. 81:279-285.

34. Zachenhofer I, Donat M, Oberndorfer S, Roessler K (2010) Perioperative levetiracetam for prevention of seizures in supratentorial brain tumor surgery. $\mathrm{J}$ Neurooncol. [Epub ahead of print] 
35. De Santis A, Villani R, Sinisi M, Stocchetti N, Perucca E (2002) Add-on phenytoin fails to prevent early seizures after surgery for supratentorial brain tumors: a randomized controlled study. Epilepsia. 43:175-182.

36. Lynch BA, Lambeng N, Nocka K, Kensel-Hammes P, Bajjalieh SM, Matagne A, Fuks B (2004) The synaptic vesicle protein SV2A is the binding site for the antiepileptic drug levetiracetam. Proc Natl Acad Sci U S A. 29;101:9861-9866.

37. Dinapoli L, Maschio M, Jandolo B, Fabi A, Pace A, Sperati F, Muti P (2009) Quality of life and seizure control in patients with brain tumor-related epilepsy treated with levetiracetam monotherapy: preliminary data of an open-label study. Neurol Sci 30:353-359.

38. Lim DA, Tarapore P, Chang E, Burt M, Chakalian L, Barbaro N, Chang S, Lamborn KR, McDermott MW (2009): Safety and feasibility of switching from phenytoin to levetiracetam monotherapy for glioma-related seizure control following craniotomy: a randomized phase II study. J Neurooncol 93:349-354.

39. Usery JB, Michael LM 2nd, Sills AK, Finch CK (2010) A prospective evaluation and literature review of levetiracetam use in patients with brain tumors and seizures. J Neurooncol. [Epub ahead of print]

40. Newton HB, Dalton J, Goldlust S, Pearl D (2007) Retrospective analysis of the efficacy and tolerability of levetiracetam in patients with metastatic brain tumors. J Neurooncol. 84:293-296.

41. Newton HB, Goldlust SA, Pearl D (2006) Retrospective analysis of the efficacy and tolerability of levetiracetam in brain tumor patients. J Neurooncol. 78:99102. 
42. Maschio M, Albani F, Baruzzi A, Zarabla A, Dinapoli L, Pace A, Pompili A, Carapella CM, Occhipinti E, Jandolo B (2006) Levetiracetam therapy in patients with brain tumour and epilepsy. J Neurooncol. 80:97-100.

43. Lee JW, Bromfield EB, Kesari S (2008) Antiemetic properties of the antiepileptic drug levetiracetam. N Engl J Med 359:1853.

44. van Breemen MS, Rijsman RM, Taphoorn MJ, Walchenbach R, Zwinkels H, Vecht CJ (2009) Efficacy of anti-epileptic drugs in patients with gliomas and seizures. J Neurol. 256:1519-1526.

45. Maschio M, Dinapoli L, Zarabla A, Pompili A, Carapella CM, Pace A, Giannarelli D, Occhipinti E, Jandolo B (2008) Outcome and tolerability of topiramate in brain tumor associated epilepsy. J Neurooncol. 86:61-70.

46. Maschio M, Dinapoli L, Vidiri A, Pace A, Fabi A, Pompili A, Carapella MC, Jandolo B (2009) The role side effects play in the choice of antiepileptic therapy in brain tumor-related epilepsy: a comparative study on traditional antiepileptic drugs versus oxcarbazepine. J Exp Clin Cancer Res. 28:60.

47. Vecht CJ, Wilms EB (2010) Seizures in low- and high-grade gliomas: current management and future outlook. Expert Rev Anticancer Ther. 10:663-669.

48. Perry JR, Sawka C (1996) Add-on gabapentin for refractory seizures in patients with brain tumours. Can J Neurol Sci. 23:128-131.

49. Striano S, Striano P, Boccella P, Nocerino C, Bilo L (2002) Tiagabine in glial tumors. Epilepsy Res. 49:81-85.

50. Novy J, Stupp R, Rossetti AO (2009) Pregabalin in patients with primary brain tumors and seizures: a preliminary observation. Clin Neurol Neurosurg. 111:171-173. 
51. Maschio M, Dinapoli L, Gomellini S, Ferraresi V, Sperati F, Vidiri A, Muti P, Jandolo B (2010) Antiepileptics in brain metastases: safety, efficacy and impact on life expectancy. J Neurooncol. 98:109-116.

52. Cohen N, Strauss G, Lew R, Silver D, Recht L (1988) Should prophylactic anticonvulsants be administered to patients with newly-diagnosed cerebral metastases? A retrospective analysis. J Clin Oncol 6:1621-1624.

53. Drane DL, Meador KJ (2002) Cognitive and behavioral effects of antiepileptic drugs. Epilepsy Behav. 3:49-53.

54. Delattre J, Safai B, Posner JB (1988) Erythema multiforme and Stevens-Johnson syndrome in patients receiving cranial irradiation and phenytoin. Neurology 38:194-198.

55. Khe HX, Delattre JY, Poisson M (1990) Stevens-Johnson syndrome in a patient receiving cranial irradiation and carbamazepine. Neurology 40:1144-1145.

56. Mamon HJ, Wen PY, Burns AC, Loeffler JS (1999) Allergic skin reactions to anticonvulsant medications in patients receiving cranial radiation therapy. Epilepsia. 40:341-344.

57. Aguiar D, Pazo R, Duran I, Terrasa J, Arrivi A, Manzano H, Martin J, Rifa J (2004) Toxic epidermal necrolysis in patients receiving anticonvulsants and cranial irradiation: A risk to consider. J Neurooncol. 66:345-350.

58. Klein M, Heimans JJ, Aaronson NK, van der Ploeg HM, Grit J, Muller M, Postma TJ, Mooij JJ, Boerman RH, Beute GN, Ossenkoppele GJ, van Imhoff GW, Dekker AW, Jolles J, Slotman BJ, Struikmans H, Taphoorn MJ (2002) Effect of radiotherapy and other treatment-related factors on mid-term to longterm cognitive sequelae in low-grade gliomas: a comparative study. Lancet. 360:1361-1368. 
59. Perucca E (2006) Clinically relevant drug interactions with antiepileptic drugs. Br J Clin Pharmacol. 61:246-255.

60. Yap KY, Chui WK, Chan A (2008) Drug interactions between chemotherapeutic regimens and antiepileptics. Clin Ther. 30:1385-1407.

61. Vecht CJ, Wagner GL, Wilms EB (2003) Interactions between antiepileptic and chemotherapeutic drugs. Lancet Neurol. 2:404-409.

62. Ruggiero A, Rizzo D, Mastrangelo S, Battaglia D, Attinà G, Riccardi R (2010) Interactions between antiepileptic and chemotherapeutic drugs in children with brain tumors: is it time to change treatment? Pediatr Blood Cancer 54:193-198.

63. Pursche S, Schleyer E, von Bonin M, Ehninger G, Said SM, Prondzinsky R, Illmer T, Wang Y, Hosius C, Nikolova Z, Bornhäuser M, Dresemann G (2008) Influence of enzyme-inducing antiepileptic drugs on trough level of imatinib in glioblastoma patients. Curr Clin Pharmacol. 3:198-203.

64. Raizer JJ, Abrey LE, Lassman AB, Chang SM, Lamborn KR, Kuhn JG, Yung WK, Gilbert MR, Aldape KD, Wen PY, Fine HA, Mehta M, Deangelis LM, Lieberman F, Cloughesy TF, Robins HI, Dancey J, Prados MD; North American Brain Tumor Consortium (2010) A phase I trial of erlotinib in patients with nonprogressive glioblastoma multiforme postradiation therapy, and recurrent malignant gliomas and meningiomas. Neuro Oncol. 12:87-94.

65. Avila EK, Graber J (2010) Seizures and epilepsy in cancer patients. Curr Neurol Neurosci Rep. 10:60-67.

66. Sisodiya SM (2003) Mechanisms of antiepileptic drug resistance. Curr Opin Neurol 16:197-201.

67. Calatozzolo C, Gelati M, Ciusani E, Sciacca FL, Pollo B, Cajola L, Marras C, Silvani A, Vitellaro-Zuccarello L, Croci D, Boiardi A, Salmaggi A (2005) 
Expression of drug resistance proteins Pgp, MRP1, MRP3, MRP5 and GST-pi in human glioma. J Neurooncol. 74:113-121.

68. Gottlicher M, Minucci S, Zhu P, Krämer OH, Schimpf A, Giavara S, Sleeman JP, Lo Coco F, Nervi C, Pelicci PG, Heinzel T (2001) Valproic acid defines a novel class of HDAC inhibitors inducing differentiation of transformed cells. EMBO J 20:6969-6978.

69. Phiel CJ, Zhang F, Huang EY, Guenther MG, Lazar MA, Klein PS (2001) Histone deacetylase is a direct target of valproic acid, a potent anticonvulsant, mood stabilizer, and teratogen. J Biol Chem 276:36734-36741.

70. Duenas-Gonzalez A, Candelaria M, Perez-Plascencia C, Perez-Cardenas E, de la Cruz-Hernandez E, Herrera LA (2008). Valproic acid as epigenetic cancer drug: preclinical, clinical and transcriptional effects on solid tumors. Cancer Treat Rev. 34:206-222.

71. Benítez JA, Arregui L, Cabrera G, Segovia J (2008) Valproic acid induces polarization, neuronal-like differentiation of a subpopulation of C6 glioma cells and selectively regulates transgene expression. Neuroscience 156:911-920.

72. Cinatl J Jr, Kotchetkov R, Blaheta R, Driever PH, Vogel JU, Cinatl J (2002) Induction of differentiation and suppression of malignant phenotype of human neuroblastoma BE(2)-C cells by valproic acid: enhancement by combination with interferon-alpha. Int J Oncol. 20:97-106.

73. Häcker S, Dittrich A, Mohr A, Schweitzer T, Rutkowski S, Krauss J, Debatin KM, Fulda S (2009) Histone deacetylase inhibitors cooperate with IFN-gamma to restore caspase- 8 expression and overcome TRAIL resistance in cancers with silencing of caspase-8. Oncogene 28:3097-3110. 
74. Knüpfer MM, Pulzer F, Schindler I, Hernaíz Driever P, Knüpfer H, Keller E (2001) Different effects of valproic acid on proliferation and migration of malignant glioma cells in vitro. Anticancer Res. 21:347-351.

75. Das CM, Aguilera D, Vasquez H, Prasad P, Zhang M, Wolff JE, Gopalakrishnan V (2007) Valproic acid induces p21 and topoisomerase-II (alpha/beta) expression and synergistically enhances etoposide cytotoxicity in human glioblastoma cell lines. J Neurooncol. 85:159-170.

76. Li XN, Shu Q, Su JM, Perlaky L, Blaney SM, Lau CC (2005) Valproic acid induces growth arrest, apoptosis, and senescence in medulloblastomas by increasing histone hyperacetylation and regulating expression of p21Cip1, CDK4, and CMYC. Mol Cancer Ther. 4:1912-1922.

77. Venkataramani V, Rossner C, Iffland L, Schweyer S, Tamboli IY, Walter J, Wirths O, Bayer TA (2010) Histone deacetylase inhibitor valproic acid inhibits cancer cell proliferation via down-regulation of the alzheimer amyloid precursor protein. J Biol Chem. 285:10678-10689.

78. Papi A, Ferreri AM, Rocchi P, Guerra F, Orlandi M (2010) Epigenetic modifiers as anticancer drugs: effectiveness of valproic acid in neural crest-derived tumor cells. Anticancer Res. 30:535-540.

79. Shu Q, Antalffy B, Su JM, Adesina A, Ou CN, Pietsch T, Blaney SM, Lau CC, Li XN (2006) Valproic Acid prolongs survival time of severe combined immunodeficient mice bearing intracerebellar orthotopic medulloblastoma xenografts. Clin Cancer Res. 12:4687-4694.

80. Ciusani E, Balzarotti M, Calatozzolo C, de Grazia U, Boiardi A, Salmaggi A, Croci D (2007) Valproic acid increases the in vitro effects of nitrosureas on human glioma cell lines. Oncol Res.16:453-463. 
81. Jawed S, Kim B, Ottenhof T, Brown GM, Werstiuk ES, Niles LP (2007) Human melatonin MT1 receptor induction by valproic acid and its effects in combination with melatonin on MCF-7 breast cancer cell proliferation. Eur J Pharmacol. 560:17-22.

82. Fu J, Shao CJ, Chen FR, Ng HK, Chen ZP (2010) Autophagy induced by valproic acid is associated with oxidative stress in glioma cell lines. Neuro Oncol.12:328-340.

83. Camphausen K, Cerna D, Scott T, Sproull M, Burgan WE, Cerra MA, Fine H, Tofilon PJ (2005) Enhancement of in vitro and in vivo tumor cell radiosensitivity by valproic acid. Int J Cancer. 114:380-386.

84. Chinnaiyan P, Cerna D, Burgan WE, Beam K, Williams ES, Camphausen K, Tofilon PJ (2008) Postradiation sensitization of the histone deacetylase inhibitor valproic acid. Clin Cancer Res. 14:5410-5415.

85. Bobustuc GC, Baker CH, Limaye A, Jenkins WD, Pearl G, Avgeropoulos NG, Konduri SD (2010) Levetiracetam enhances p53-mediated MGMT inhibition and sensitizes glioblastoma cells to temozolomide. Neuro Oncol. 12:917-927.

86. Silber JR, Mueller BA, Ewers TG, Berger MS (1993): Comparison of O6methylguanine-DNA methyltransferase activity in brain tumors and adjacent normal brain. Cancer Res. 53:3416-3420.

87. Hegi ME, Diserens AC, Gorlia T, Hamou MF, de Tribolet N, Weller M, Kros JM, Hainfellner JA, Mason W, Mariani L, Bromberg JE, Hau P, Mirimanoff RO, Cairncross JG, Janzer RC, Stupp R (2005) MGMT gene silencing and benefit from temozolomide in glioblastoma. N Engl J Med. 352:997-1003.

88. Oberndorfer S, Piribauer M, Marosi C, Lahrmann H, Hitzenberger P, Grisold W (2005) P450 enzyme inducing and non-enzyme inducing antiepileptics in 
glioblastoma patients treated with standard chemotherapy. J Neurooncol. $72: 255-260$.

89. Jaeckle KA, Ballman K, Furth A, Buckner JC (2009) Correlation of enzymeinducing anticonvulsant use with outcome of patients with glioblastoma. Neurology 73:1207-1213.

90. Relling MV, Pui CH, Sandlund JT, Rivera GK, Hancock ML, Boyett JM, Schuetz EG, Evans WE (2000) Adverse effect of anticonvulsants on efficacy of chemotherapy for acute lymphoblastic leukaemia. Lancet 356:285-290. 


\section{Figure legends}

Figure 1. Algorithm for antiepileptic drug selection in patients with epilepsy and cancer.

*Levetiracetam is especially recommended when the primary tumor is treated with alkylating agents. $* *$ Valproic acid has anticancer activities. Frequent serum levels, complete blood count and liver function tests should be monitored. 


\begin{tabular}{|c|c|c|c|c|c|c|c|}
\hline $\begin{array}{l}\text { Chemotherape } \\
\text { utic drug }\end{array}$ & Tumor type ${ }^{* *}$ & $\begin{array}{l}\text { AED } \\
\text { accelerating } \\
\text { metabolism }\end{array}$ & $\begin{array}{l}\text { AED } \\
\text { inhibiting } \\
\text { metabolism }\end{array}$ & $\begin{array}{l}\text { Reduce } \\
\text { levels of } \\
\text { AEDs }\end{array}$ & $\begin{array}{l}\text { Increase } \\
\text { levels of } \\
\text { AEDs }\end{array}$ & Others & $\begin{array}{l}\text { Referen } \\
\text { ces }^{++}\end{array}$ \\
\hline Carboplatin & $\begin{array}{l}\text { Recurrent GBM, } \\
\text { neuroblastoma, brain } \\
\text { metastasis, lung }\end{array}$ & & & Phenytoin & & & 62 \\
\hline Cisplatin & $\begin{array}{l}\text { Recurrent GBM, } \\
\text { neuroblastoma, brain } \\
\text { metastasis, lung, } \\
\text { lymphoma }\end{array}$ & & & $\begin{array}{l}\text { Valproic } \\
\text { acid, } \\
\text { phenytoin, } \\
\text { carbamazep } \\
\text { ine }\end{array}$ & & & 3,62 \\
\hline $\begin{array}{l}\text { Cyclophospha } \\
\text { mide }\end{array}$ & $\begin{array}{l}\text { Neuroblastoma, } \\
\text { medulloblastoma, } \\
\text { malignant } \\
\text { meningioma, brain } \\
\text { metastasis, breast, } \\
\text { lymphoma }\end{array}$ & $\begin{array}{l}\text { Carbamazepine, } \\
\text { phenobarbital, } \\
\text { phenytoin, } \\
\text { primidone }\end{array}$ & $\begin{array}{l}\text { Valproic } \\
\text { acid }\end{array}$ & & & & $6,59,60$ \\
\hline Dacarbazine & $\begin{array}{l}\text { Malignant } \\
\text { meningioma, } \\
\text { melanoma, } \\
\text { lymphoma }\end{array}$ & & & Phenytoin & & & 62 \\
\hline Doxorubicin & $\begin{array}{l}\text { Neuroblastoma, } \\
\text { breast, lung, } \\
\text { lymphoma }\end{array}$ & $\begin{array}{l}\text { Carbamazepine, } \\
\text { phenobarbital, } \\
\text { phenytoin }\end{array}$ & & $\begin{array}{l}\text { Valproic } \\
\text { acid, } \\
\text { phenytoin, } \\
\text { carbamazep } \\
\text { ine }\end{array}$ & & & $3,6,60$ \\
\hline Erlotinib & $\begin{array}{l}\text { Lung, recurrent } \\
\text { GBM, malignant } \\
\text { meningioma }\end{array}$ & $\begin{array}{l}\text { Carbamazepine, } \\
\text { phenobarbital, } \\
\text { phenytoin, } \\
\text { primidone }\end{array}$ & & & & & 64 \\
\hline Etoposide & $\begin{array}{l}\text { Recurrent GBM, } \\
\text { neuroblastoma, } \\
\text { medulloblastoma, } \\
\text { brain metastasis, } \\
\text { lung }\end{array}$ & $\begin{array}{l}\text { Carbamazepine, } \\
\text { phenobarbital, } \\
\text { phenytoin, } \\
\text { primidone }\end{array}$ & & Phenytoin & & & $6,59,62$ \\
\hline Fluorouracil & $\begin{array}{l}\text { Brain metastasis, } \\
\text { breast, colorectal }\end{array}$ & & & & Phenytoin & & $3,59,60$ \\
\hline Ifosfamide & $\begin{array}{l}\text { Malignant } \\
\text { meningioma, } \\
\text { neuroblastoma, } \\
\text { metastatic brain, } \\
\text { breast, lymphoma, } \\
\text { lung }\end{array}$ & $\begin{array}{l}\text { Carbamazepine, } \\
\text { phenobarbital, } \\
\text { phenytoin, } \\
\text { primidone }\end{array}$ & & & & & $6,59,62$ \\
\hline Imatinib & Recurrent GBM & $\begin{array}{l}\text { Carbamazepine, } \\
\text { phenobarbital, } \\
\text { phenytoin, } \\
\text { primidone }\end{array}$ & & & & & 63 \\
\hline Irinotecan & $\begin{array}{l}\text { Recurrent GBM, } \\
\text { colorectal, lung, } \\
\text { brain metastasis }\end{array}$ & $\begin{array}{l}\text { Phenytoin, } \\
\text { phenobarbital, } \\
\text { carbamazepine, } \\
\text { primidone }\end{array}$ & & & & & $6,59,60$ \\
\hline Ixabepilone & Breast & $\begin{array}{l}\text { Phenytoin, } \\
\text { phenobarbital, } \\
\text { carbamazepine }\end{array}$ & & & & & 60 \\
\hline Methotrexate & Lymphoma & $\begin{array}{l}\text { Carbamazepine, } \\
\text { phenytoin, } \\
\text { phenobarbital }\end{array}$ & & $\begin{array}{l}\text { Valproic } \\
\text { acid, } \\
\text { phenytoin }\end{array}$ & & & $\begin{array}{l}3,6,59 \\
60,90\end{array}$ \\
\hline Nitrosoureas & Recurrent GBM, & Carbamazepine, & & Phenytoin & & & $6,59,62$ \\
\hline
\end{tabular}




\begin{tabular}{|c|c|c|c|c|c|c|c|}
\hline $\begin{array}{l}\text { Chemotherape } \\
\text { utic drug }\end{array}$ & Tumor type ${ }^{* *}$ & $\begin{array}{l}\text { AED } \\
\text { accelerating } \\
\text { metabolism }\end{array}$ & $\begin{array}{l}\text { AED } \\
\text { inhibiting } \\
\text { metabolism }\end{array}$ & $\begin{array}{l}\text { Reduce } \\
\text { levels of } \\
\text { AEDs }\end{array}$ & $\begin{array}{l}\text { Increase } \\
\text { levels of } \\
\text { AEDs }\end{array}$ & Others & $\begin{array}{l}\text { Referen } \\
\text { ces }^{++}\end{array}$ \\
\hline $\begin{array}{l}\text { (carmustine, } \\
\text { lomustine) }\end{array}$ & $\begin{array}{l}\text { medulloblastoma, } \\
\text { brain metastasis }\end{array}$ & $\begin{array}{l}\text { phenobarbital, } \\
\text { phenytoin, } \\
\text { primidone }\end{array}$ & & & & & \\
\hline Paclitaxel & $\begin{array}{l}\text { Brain metastasis, } \\
\text { breast, lung }\end{array}$ & $\begin{array}{l}\text { Carbamazepine, } \\
\text { phenobarbital, } \\
\text { phenytoin, } \\
\text { primidone }\end{array}$ & & & & & $6,59,60$ \\
\hline Procarbazine & $\begin{array}{l}\text { Medulloblastoma, } \\
\text { lymphoma }\end{array}$ & $\begin{array}{l}\text { Carbamazepine, } \\
\text { phenobarbital, } \\
\text { phenytoin, } \\
\text { primidone }\end{array}$ & & & & $\begin{array}{l}\text { Contrain } \\
\text { dicated } \\
\text { with } \\
\text { carbama } \\
\text { zepine }\end{array}$ & $\begin{array}{l}59,60, \\
62\end{array}$ \\
\hline Sunitinib & Renal & $\begin{array}{l}\text { Carbamazepine, } \\
\text { phenobarbital, } \\
\text { phenytoin, } \\
\text { primidone }\end{array}$ & & & & & 60 \\
\hline Tamoxifen & Breast & Phenobarbital & $\begin{array}{l}\text { Valproic } \\
\text { acid }\end{array}$ & & Phenytoin & & $6,59,60$ \\
\hline Tegafur & $\begin{array}{l}\text { Brain metastasis, } \\
\text { colorectal }\end{array}$ & & & & Phenytoin & & 3,59 \\
\hline Temozolomide & $\begin{array}{l}\text { GBM, low-grade } \\
\text { glioma, brain } \\
\text { metastasis }\end{array}$ & - & - & & & & 62 \\
\hline Teniposide & Brain metastasis & $\begin{array}{l}\text { Carbamazepine, } \\
\text { phenobarbital, } \\
\text { phenytoin, } \\
\text { primidone }\end{array}$ & & & & & $\begin{array}{l}6,59,62, \\
90\end{array}$ \\
\hline Thiotepa & $\begin{array}{l}\text { Medulloblastoma, } \\
\text { metastatic brain, } \\
\text { lymphoma, breast }\end{array}$ & $\begin{array}{l}\text { Carbamazepine, } \\
\text { phenobarbital, } \\
\text { phenytoin, } \\
\text { primidone }\end{array}$ & & & & & $6,59,62$ \\
\hline Topotecan & $\begin{array}{l}\text { Neuroblastoma, } \\
\text { lymphoma, brain } \\
\text { metastasis }\end{array}$ & $\begin{array}{l}\text { Carbamazepine, } \\
\text { phenobarbital, } \\
\text { phenytoin, } \\
\text { primidone }\end{array}$ & & & & & $6,59,62$ \\
\hline Vinblastine & $\begin{array}{l}\text { Lymphoma, lung, } \\
\text { breast }\end{array}$ & $\begin{array}{l}\text { Carbamazepine, } \\
\text { phenobarbital, } \\
\text { phenytoin, } \\
\text { primidone }\end{array}$ & & Phenytoin & & & 6,59 \\
\hline Vincristine & $\begin{array}{l}\text { Recurrent GBM, } \\
\text { neuroblastoma, } \\
\text { medulloblastoma, } \\
\text { malignant } \\
\text { meningioma, } \\
\text { lymphoma }\end{array}$ & $\begin{array}{l}\text { Carbamazepine, } \\
\text { phenobarbital, } \\
\text { phenytoin }\end{array}$ & & $\begin{array}{l}\text { Phenytoin, } \\
\text { carbamazep } \\
\text { ine }\end{array}$ & & & $\begin{array}{l}3,6,59 \\
60\end{array}$ \\
\hline Vorinostat & $\begin{array}{l}\text { Lymphoma, } \\
\text { recurrent GBM }\end{array}$ & & & & & $\begin{array}{l}\text { Frequent } \\
\text { monitori } \\
\text { ng with } \\
\text { valproic } \\
\text { acid }\end{array}$ & 60,62 \\
\hline
\end{tabular}

\footnotetext{
* Some of the displayed interactions represent the predicted consequences from drug co-administration based on each drug metabolism, rather than experimentally proved ones.

${ }^{+}$These drug interactions are not exclusive neither unique between the co-administrated drugs.

${ }^{* * *}$ Referring to some of the tumors types that each chemotherapeutic agent is used or has been tested.

${ }^{++}$Numbers correspond to references in the reference list of the text
} 


\begin{tabular}{l|l|l|l|l|l|l|l}
\hline \multicolumn{1}{l}{ Table 1: Common interactions between antiepileptic and chemotherapeutic drugs ${ }^{*},+$} \\
\hline $\begin{array}{l}\text { Chemotherape } \\
\text { utic drug }\end{array}$ & Tumor type* $^{* *}$ & $\begin{array}{l}\text { AED } \\
\text { accelerating } \\
\text { metabolism }\end{array}$ & $\begin{array}{l}\text { AED } \\
\text { inhibiting } \\
\text { metabolism }\end{array}$ & $\begin{array}{l}\text { Reduce } \\
\text { levels of } \\
\text { AEDs }\end{array}$ & $\begin{array}{l}\text { Increase } \\
\text { levels of } \\
\text { AEDs }\end{array}$ & Others & $\begin{array}{l}\text { Referen } \\
\text { ces }^{++}\end{array}$ \\
\hline
\end{tabular}

GBM: glioblastoma multiforme; AED: antiepileptic drug. 
Table 2: Indicative pre-clinical studies of valproic acid's anticancer effect

\begin{tabular}{|c|c|c|}
\hline Tumor type & Effect & Reference \\
\hline C6 glioma cell in vitro & $\begin{array}{l}\text { Inhibition of proliferation, migration; } \\
\text { neuronal-like differentiation }\end{array}$ & Benítez et al, 2008 \\
\hline $\begin{array}{l}\text { Malignant glioma cell } \\
\text { lines in vitro }\end{array}$ & $\begin{array}{l}\text { Inhibition of proliferation of } 86 \mathrm{HG} 39 \text {, } \\
\text { A172, 85HG66 cell lines; inhibition of } \\
\text { migration in T98G and } 85 \mathrm{HG} 66 \text { cell } \\
\text { lines }\end{array}$ & Knüpfer et al, 2001 \\
\hline $\begin{array}{l}\text { Human glioma cell lines } \\
\text { in vitro }\end{array}$ & $\begin{array}{l}\text { Enhancement of radiosensitivity; } \\
\text { accumulation in } G(2)-M \text { cell cycle phase }\end{array}$ & Chinnaiyan et al, 2008 \\
\hline $\begin{array}{l}\text { Malignant glioma cell } \\
\text { lines in vitro and in vivo }\end{array}$ & $\begin{array}{l}\text { Enhancement of radiosensitivity; in vivo } \\
\text { tumor growth delay }\end{array}$ & Camphausen et L, 2005 \\
\hline $\begin{array}{l}\text { Malignant glioma cell } \\
\text { lines in vitro }\end{array}$ & $\begin{array}{l}\text { G(1) or G(2) phase accumulation; } \\
\text { induction of p21/WAF1, topoisomerase- } \\
\text { II and GFAP; enhancement of etoposide } \\
\text { cytotoxicity }\end{array}$ & Das et al, 2007 \\
\hline $\begin{array}{l}\text { Glioma cell lines in vitro } \\
\text { and in vivo }\end{array}$ & $\begin{array}{l}\text { Induction of autophagy; synergistic } \\
\text { effect with rapamycin, Ly294002 and } \\
\text { temozolomide }\end{array}$ & Fu et al, 2010 \\
\hline $\begin{array}{l}\text { Human glioma cell lines } \\
\text { in vitro }\end{array}$ & $\begin{array}{l}\text { Synergistic effect with nitrosureas; } \\
\text { inhibition of cell proliferation }\end{array}$ & Ciusani et al, 2007 \\
\hline $\begin{array}{l}\text { human glioblastoma, } \\
\text { melanoma and SKNMC } \\
\text { tumor cell lines, in vitro }\end{array}$ & $\begin{array}{l}\text { growth inhibition; apoptosis; down- } \\
\text { regulation of MMP-2 and MMP-9; } \\
\text { increase of TIMP1; inhibition of } \\
\text { migration }\end{array}$ & Papi et al, 2010 \\
\hline $\begin{array}{l}\text { Medulloblastoma cell } \\
\text { lines in vitro and in vivo }\end{array}$ & $\begin{array}{l}\text { Together with interferon-gamma restore } \\
\text { caspase- } 8 \text { expression and sensitize to } \\
\text { TRAIL-induced cell death }\end{array}$ & Häcker et al, 2009 \\
\hline $\begin{array}{l}\text { Medulloblastoma cell } \\
\text { lines in vivo }\end{array}$ & $\begin{array}{l}\text { Prolongation of survival; inhibition of } \\
\text { proliferation and angiogenesis; } \\
\text { apoptosis; differentiation }\end{array}$ & Shu et al, 2006 \\
\hline $\begin{array}{l}\text { Medulloblastoma cell } \\
\text { lines in vitro and in vivo }\end{array}$ & $\begin{array}{l}\text { Cell cycle arrest; apoptosis; senescence; } \\
\text { differentiation; activation of p } 21 \text {; } \\
\text { suppression of TP53, CDK } 4 \text { and C-myc; } \\
\text { inhibition of tumor growth in vivo }\end{array}$ & Li et al, 2005 \\
\hline $\begin{array}{l}\text { Pancreatic and colon cell } \\
\text { lines in vitro }\end{array}$ & $\begin{array}{l}\text { Up-regulation of GRP78; inhibition of } \\
\text { APP; inhibition of cell proliferation }\end{array}$ & Venkataramani et al, 2010 \\
\hline Neuroblastoma model & $\begin{array}{l}\text { Synergistic effect with interferon-alpha; } \\
\text { inhibition of cell growth; neuronal } \\
\text { differentiation; down-regulation of } \mathrm{N} \text { - } \\
\text { myc, up-regulation of bcl-2 and neuronal } \\
\text { adhesion molecule; up-regulation of } \\
\text { thrombospondin- } 1 \text { and activin A }\end{array}$ & Cinatl et al, 2002 \\
\hline $\begin{array}{l}\text { Human breast cancer cell } \\
\text { lines in vitro }\end{array}$ & $\begin{array}{l}\text { Up-regulation of MT1 receptor; } \\
\text { inhibition of proliferation with } \\
\text { melatonin }\end{array}$ & Jawed et al, 2007 \\
\hline \multicolumn{3}{|c|}{$\begin{array}{l}\text { GFAP: glial fibrillary acidic protein; MMP: matrix metalloproteinases; TIMP: tissue inhibitor of } \\
\text { matrix metalloproteinases; TRAIL: tumor necrosis factor-related apoptosis-inducing ligand; CDK: } \\
\text { cyclin-dependent kinase; TP53: tumor protein 53; GRP78: glucose regulate protein 78; APP: beta- } \\
\text { amyloid precursor protein; MT1: melatonin. }\end{array}$} \\
\hline
\end{tabular}




\begin{tabular}{|c|c|c|c|c|c|}
\hline \multicolumn{6}{|c|}{ Table 3 : Summary of important findings from clinical trials analyzed in the manuscript } \\
\hline Study & $\begin{array}{l}\text { No of } \\
\text { patients }\end{array}$ & Diagnosis & $\begin{array}{l}\text { Anticonvulsant } \\
\text { agent }\end{array}$ & Conclusions & Reference \\
\hline $\begin{array}{l}\text { Meta-analysis of } 4 \\
\text { randomized clinical } \\
\text { trials and } 8 \text { cohort } \\
\text { studies to assess } \\
\text { efficacy of } \\
\text { prophylactic } \\
\text { anticonvulsant } \\
\text { medication in cancer } \\
\text { patients }\end{array}$ & 1017 & $\begin{array}{l}\text { Brain } \\
\text { metastasis, } \\
\text { glioma, } \\
\text { meningioma, } \\
\text { sellar tumor }\end{array}$ & $\begin{array}{l}\text { Phenytoin, } \\
\text { valproic acid, } \\
\text { phenobarbital, } \\
\text { others }\end{array}$ & $\begin{array}{l}\text { Prophylactic } \\
\text { administration of } \\
\text { AEDs is not } \\
\text { indicated, AED- } \\
\text { associated side } \\
\text { effects are } \\
\text { especially } \\
\text { common and } \\
\text { occasionally } \\
\text { life-threatening } \\
\end{array}$ & $\begin{array}{l}\text { Glantz et al, } \\
2000\end{array}$ \\
\hline $\begin{array}{l}\text { Meta-analysis of five } \\
\text { prospective } \\
\text { randomized } \\
\text { controlled trials to } \\
\text { assess efficacy of } \\
\text { prophylactic } \\
\text { anticonvulsant } \\
\text { medication in brain } \\
\text { tumors }\end{array}$ & 403 & $\begin{array}{l}\text { Brain } \\
\text { metastasis, } \\
\text { glioma, } \\
\text { meningioma }\end{array}$ & $\begin{array}{l}\text { Phenytoin, } \\
\text { valproic acid, } \\
\text { phenobarbital }\end{array}$ & $\begin{array}{l}\text { No evidence for } \\
\text { AED } \\
\text { prophylaxis in } \\
\text { patients with } \\
\text { brain tumors and } \\
\text { no history of } \\
\text { seizures }\end{array}$ & $\begin{array}{l}\text { Sirven et al, } \\
2004\end{array}$ \\
\hline $\begin{array}{l}\text { Prospective study } \\
\text { about seizure } \\
\text { incidence and role of } \\
\text { prophylactic } \\
\text { anticonvulsants }\end{array}$ & 64 & Glioma & $\begin{array}{l}\text { Phenytoin, } \\
\text { levetiracetam }\end{array}$ & $\begin{array}{l}\text { Prophylactic } \\
\text { AED treatment } \\
\text { is not justified }\end{array}$ & $\begin{array}{l}\text { Rosati et al, } \\
2009\end{array}$ \\
\hline $\begin{array}{l}\text { Prospective } \\
\text { randomized study on } \\
\text { the efficacy of } \\
\text { prophylactic AEDs in } \\
\text { brain tumor patients }\end{array}$ & 100 & $\begin{array}{l}\text { Metastatic } \\
\text { and primary } \\
\text { brain tumors }\end{array}$ & $\begin{array}{l}\text { Phenytoin, } \\
\text { phenobarbital }\end{array}$ & $\begin{array}{l}\text { Prophylactic } \\
\text { AED therapy is } \\
\text { not justified }\end{array}$ & $\begin{array}{l}\text { Forsyth et al, } \\
2003\end{array}$ \\
\hline $\begin{array}{l}\text { Prospective study on } \\
\text { the efficacy of } \\
\text { prophylactic AEDs in } \\
\text { surgically treated } \\
\text { supratentorial } \\
\text { neoplasms }\end{array}$ & 128 & $\begin{array}{l}\text { Supratentorial } \\
\text { neoplasms }\end{array}$ & $\begin{array}{l}\text { Phenytoin, } \\
\text { phenobarbital }\end{array}$ & $\begin{array}{l}\text { Benefit of a } \\
\text { short term } \\
\text { preventive } \\
\text { treatment with } \\
\text { AEDs after } \\
\text { surgery } \\
\end{array}$ & $\begin{array}{l}\text { Franceschetti } \\
\text { et al, } 1990\end{array}$ \\
\hline $\begin{array}{l}\text { Retrospective } \\
\text { analysis of the } \\
\text { efficacy and } \\
\text { tolerability of } \\
\text { levetiracetam as } \\
\text { perioperative seizure } \\
\text { prophylaxis in } \\
\text { supratentorial brain } \\
\text { tumors }\end{array}$ & 78 & $\begin{array}{l}\text { Glioma, } \\
\text { meningioma, } \\
\text { primary CNS } \\
\text { lymphoma, } \\
\text { brain } \\
\text { metastasis, } \\
\text { radiation } \\
\text { necrosis }\end{array}$ & Levetiracetam & $\begin{array}{l}\text { Low }(2.5 \%) \\
\text { seizure } \\
\text { frequency in the } \\
\text { early } \\
\text { postoperative } \\
\text { period with } \\
\text { levetiracetam; } \\
\text { drug well } \\
\text { tolerated }\end{array}$ & $\begin{array}{l}\text { Zachenhofer } \\
\text { et al, } 2010\end{array}$ \\
\hline $\begin{array}{l}\text { Retrospective } \\
\text { analysis of the } \\
\text { effectiveness of } \\
\text { levetiracetam in brain } \\
\text { tumors }\end{array}$ & 41 & $\begin{array}{l}\text { Glioma, } \\
\text { primary CNS } \\
\text { lymphoma, } \\
\text { brain } \\
\text { metastasis } \\
\end{array}$ & Levetiracetam & $\begin{array}{l}\text { Levetiracetam } \\
\text { proved very } \\
\text { effective in brain } \\
\text { tumor patients } \\
\text { with seizures } \\
\end{array}$ & $\begin{array}{l}\text { Newton et } \\
\text { al, } 2006\end{array}$ \\
\hline $\begin{array}{l}\text { Observational study } \\
\text { on the efficacy of } \\
\text { AEDs in patients } \\
\text { with brain tumors } \\
\text { and seizures }\end{array}$ & 99 & $\begin{array}{l}\text { Glioma, } \\
\text { ependymoma, } \\
\text { meningioma, } \\
\text { brain } \\
\text { metastasis }\end{array}$ & $\begin{array}{l}\text { Valproic acid, } \\
\text { levetiracetam, } \\
\text { carbamazepin, } \\
\text { lamotrigine }\end{array}$ & $\begin{array}{l}\text { The combination } \\
\text { of valproic acid } \\
\text { and } \\
\text { levetiracetam } \\
\text { proved the most } \\
\text { efficient }\end{array}$ & $\begin{array}{l}\text { van Breemen } \\
\text { et al, } 2009\end{array}$ \\
\hline
\end{tabular}




\begin{tabular}{|c|c|c|c|c|c|}
\hline $\begin{array}{l}\text { Retrospective } \\
\text { analysis of the } \\
\text { efficacy, safety and } \\
\text { impact on life } \\
\text { expectancy of } \\
\text { levetiracetam, } \\
\text { oxcarbazepine and } \\
\text { topiramate } \\
\text { monotherapy in } \\
\text { patients with seizures } \\
\text { and brain metastases }\end{array}$ & 70 & $\begin{array}{l}\text { Brain } \\
\text { metastases }\end{array}$ & $\begin{array}{l}\text { Levetiracetam, } \\
\text { oxcarbazepine, } \\
\text { topiramate }\end{array}$ & $\begin{array}{l}\text { significantly } \\
\text { reduce seizure } \\
\text { frequency, } \\
\text { produce few side } \\
\text { effects and } \\
\text { appear not to } \\
\text { affect life } \\
\text { expectancy }\end{array}$ & $\begin{array}{l}\text { Maschio et } \\
\text { al, } 2010\end{array}$ \\
\hline $\begin{array}{l}\text { Retrospective } \\
\text { analysis evaluating } \\
\text { the effects of enzyme } \\
\text { inducing and non- } \\
\text { enzyme inducing } \\
\text { AEDs in patients } \\
\text { with GBM treated } \\
\text { with standard } \\
\text { chemotherapeutic } \\
\text { agents on survival } \\
\text { and hematotoxicity }\end{array}$ & 168 & GBM & $\begin{array}{l}\text { Carbamazepine, } \\
\text { phenytoin, } \\
\text { valproic acid }\end{array}$ & $\begin{array}{l}\text { Significantly } \\
\text { increased } \\
\text { survival with } \\
\text { non-enzyme } \\
\text { inducing AEDs } \\
\text { compared to } \\
\text { enzyme inducing } \\
\text { AEDs; increased } \\
\text { hematotoxicity } \\
\text { with valproic } \\
\text { acid }\end{array}$ & $\begin{array}{l}\text { Oberndorfer } \\
\text { et al, } 2005\end{array}$ \\
\hline $\begin{array}{l}\text { Correlative analysis } \\
\text { of enzyme-inducing } \\
\text { anticonvulsants use } \\
\text { with outcome }\end{array}$ & 620 & GBM & $\begin{array}{l}\text { Enzyme and } \\
\text { non-enzyme } \\
\text { inducing AEDs }\end{array}$ & $\begin{array}{l}\text { Paradoxically, } \\
\text { enzyme- } \\
\text { inducing AEDs } \\
\text { correlated with } \\
\text { better outcome } \\
\text { of patients with } \\
\text { glioblastoma }\end{array}$ & $\begin{array}{l}\text { Jaeckle et al, } \\
2009\end{array}$ \\
\hline $\begin{array}{l}\text { Retrospective } \\
\text { analysis in children } \\
\text { to determine if AEDs } \\
\text { compromise the } \\
\text { efficacy of cancer } \\
\text { chemotherapy }\end{array}$ & 716 & $\begin{array}{l}\text { Acute } \\
\text { lymphoblastic } \\
\text { leukemia }\end{array}$ & $\begin{array}{l}\text { Phenytoin, } \\
\text { phenobarbital, } \\
\text { carbamazepine }\end{array}$ & $\begin{array}{l}\text { Enzyme } \\
\text { inducing AEDs } \\
\text { increases the } \\
\text { systemic } \\
\text { clearance of } \\
\text { several } \\
\text { antileukemic } \\
\text { agents and lower } \\
\text { efficacy of } \\
\text { chemotherapy }\end{array}$ & $\begin{array}{l}\text { Relling et al, } \\
2000\end{array}$ \\
\hline
\end{tabular}




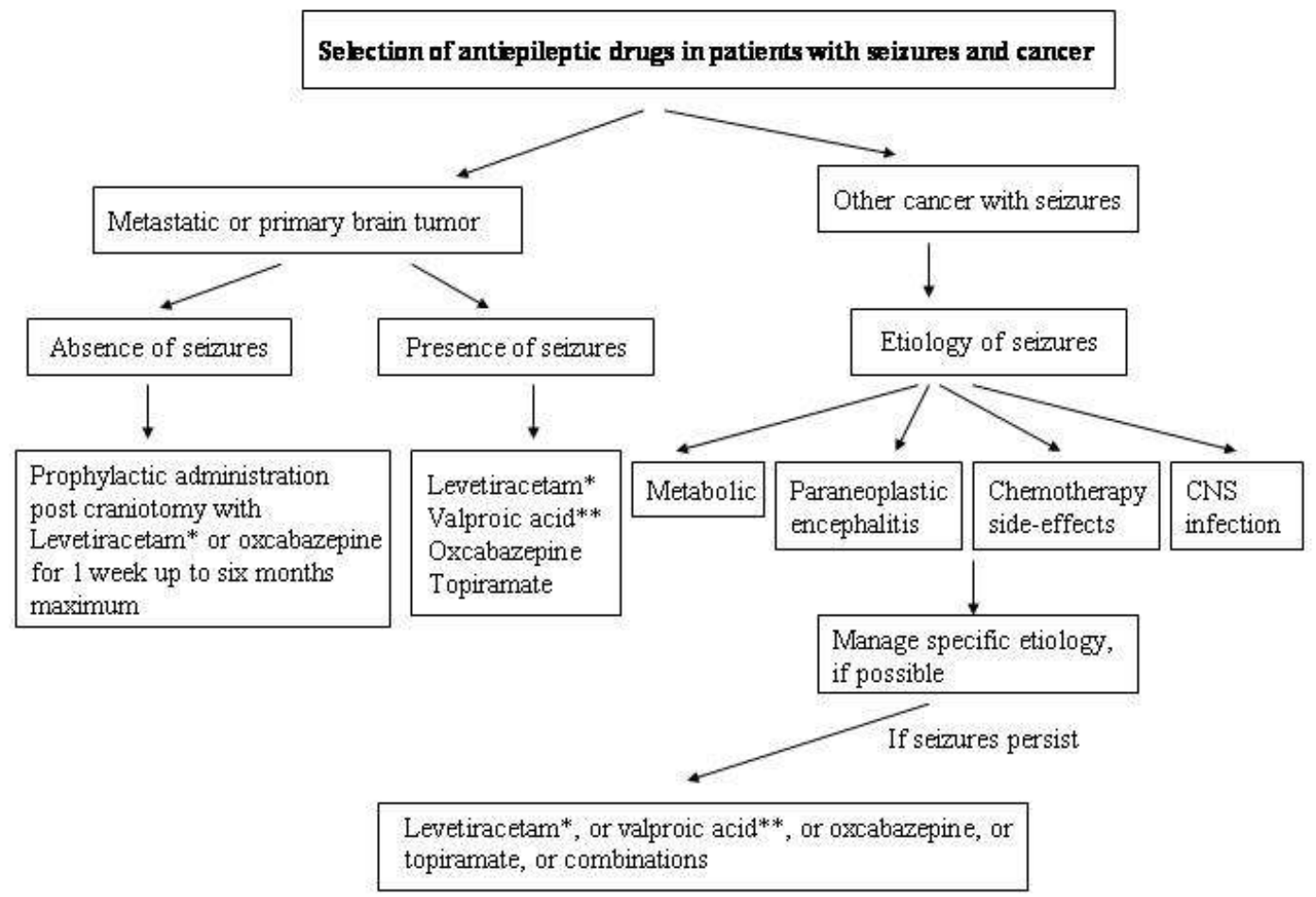

